\title{
LÉTEZIK TÖKÉLETES TANÁR? VAGY CSAK ELÉG JÓ TANÁROK VANNAK?
}

Kiváló, hiánypótló, nagyszabású munka jelent meg N. Kollár Katalin és Szabó Éva szerkesztésében. Az összesen harminckét szerző és a szerkesztők fő célkitűzése az volt, hogy összefoglaljanak a pedagógusok és a pedagógusjelöltek számára minden olyan lényeges pszichológiai ismeretet, melyre oktató-nevelő munkájuk során szükségük lehet napjaink változatos iskolai környezetében, és ezeket nagyon sok iskolai példával, azokon keresztül mutatják be három kötetben, mintegy ezer oldalon keresztül.

Annak ellenére, hogy ténylegesen nem pszichológiai szakkönyvről, hanem kézikönyvről van szó, a szerzőknek nagyon sok szakkifejezést kellett alkalmazniuk a leírások során. A szerzők ezeket minden esetben megmagyarázzák a megfelelő szövegrészekben, de külön is megtalálható a közel 350 fogalom definíciója a harmadik kötet végén. A felhasznált szakirodalom mennyisége impozáns, több mint kétezer tétel, melyekre a megfelelő szövegeknél hivatkozások történnek. Ezek tételesen a 3. kötet végén vannak felsorolva, végül név- és tárgymutató zárja ezt a kötetet, mely a szerkesztők hatalmas munkáját mutatja.

A három kötet kilenc fö fejezetet tartalmaz. Ezek összesen negyvenöt alfejezetre tagolódnak, egyenletesen elosztva az egyes kötetekben. Minden alfejezet elött részletes tartalomjegyzék található, amit egy rövid ismertetés követ a fejezet tartalmáról. Ezt követi egy bevezető rész, melynek célja az adott téma iránti érdeklődés felkeltése, több esetben motivációs kérdésekkel. A szöveg nem teljesen folyamatos, mivel további alcímek és tagoló kiemelések teszik jól áttekinthetővé a mondanivalót. Az alfejezetek végén a szerzők összefoglalják a fö mondanivalót, megadják a szövegben előforduló legfontosabb kulcsfogalmakat, kérdéseket fogalmaznak meg a leírtak aktív feldolgozáshoz, végül javasolnak néhány a témával részletesebben foglalkozó szakirodalmat, melyeket röviden ismertetnek. A szerzők minden alfejezetben sok, zömmel új kutatási eredményre hivatkoznak. A mondanivalót táblázatokkal, magyarázó ábrákkal és fényképekkel illusztrálják. Az egyes jelenségek értelmezéséhez általában többféle modellt is bemutatnak. Ki kell emelni a szerzök meleg, szeretetteljes, szinte óvó fogalmazását, mely az ifjú pedagógust segíti abban, hogy elkerüljön a pedagóguspályával együtt járó számos buktatót. A kötetekben megjelennek tabunak számító témák is, mint például a családon belüli erőszak, nemi kérdések, melyekről rendkívül korrekt ismertetéseket adnak a szerzők.

A három kötet egymást követő fejezetei ugyan egymásra épülnek, de ennek ellenére az egyes fejezetek önállóan is olvashatók. Az ismertető további részében az egyes kötetekben feldolgozott témákból válogatva emelek ki néhányat, mely megragadta a figyelmemet. 
Az elsö kötet a fejlődéspszichológiával és a tanulással kapcsolatos kérdéseket járja körül.

A legelső fő fejezet a pszichológia tudományát, az alkalmazott tudományos módszereket mutatja be. A második a személyiség alakulásának folyamataiba enged betekintést. Leszögezik, hogy a gyerek a sok-sok vele és másokkal történt esemény megfigyelésével a helyzetekre és önmagára vonatkozóan is úgynevezett sémákat alakít ki, amelyek szervezik az észlelését és irányítják a viselkedését.

A gyerek úgynevezett munkamodelleket alakít ki, amelyek mintegy tudattalan szürőként is müködnek. Ez azt jelenti, hogy a gyerek csak azokat a tapasztalatokat építi be, amelyek saját korábbi elképzeléseivel összhangban vannak, az ennek nem megfelelőket már az észlelés szintjén kizárja (85.). A 361. oldalon folytatódik a gondolatkör azzal, hogy az „észlelési beállítódások elvárásokat alakítanak ki, amelyek irányítják az észlelést, vagyis néha azt észleljük, amiről gondoljuk, hogy észlelni fogjuk". Majd a 376. oldalon tovább folytatódik a gondolatmenet a szelektív észleléssel, mely által az információt kiemeljük, más információkat pedig kiszürünk. Az az információ kerül feldolgozásra, amelyre a figyelem irányul. És ez majd elvezet a következő kötetben részletesebben tárgyalt észlelési torzításhoz, az észleléseket megkönnyítő kategorizáláshoz, majd az előítéletek kialakulásához.

A kötetben még kiváló összefoglalót lehet olvasni a veteránoktól a Z generációig és a különbözőképpen gondolkodó korosztályok együttes jelenlétének az iskolai életre gyakorolt hatásáról. A mai gyerekek a technikai fejlődés következtében ténylegesen alapvetően másként gondolkodnak, mint az idősebbek. És az oktatás világának ehhez kellene alkalmazkodni.

Ebben a kötetben előkerülnek még a családi és az iskolai szocializáció különbségei, a családi erőszak, az iskolaérettség, a stresszel kapcsolatos problémák, a különböző tanítási stílusok, néhány tanulási zavar.

A második kötet fö témaköre a személyiség jellemzöinek és az iskola szociálpszichológiai vonatkozásainak bemutatása, és az ezekkel kapcsolatos pedagógiai gyakorlat szempontjából fontos kérdések elemzése.

Mindenekelőtt leszögezik a szerzők, hogy a lelki jelenségeket az agy funkciójának kell tekinteni. Majd a híres pszichológus, Sigmund Freud elméletének néhány jellegzetességét ismertetik. Teszik ezt annak ellenére, hogy sok elképzelésével napjainkban már nem értünk egyet, ellenben a pszichológiai fejlődésére óriási hatással volt.

Meg kell említeni Donald Winnicott egyik fontos gondolatát, miszerint nincs tökéletes anya, mert ennek analógiájára mondják ki a szerzők azt a tételt, hogy egy tanár sem lehet tökéletes! Beszélhetünk „elég jó pedagógusról”, de a tanárjelölt hallgatók ne állítsanak elérhetetlen célokat maguk elé. De persze törekedjenek mindig egyre jobbnak lenni (82-83.). A témára a harmadik kötetben is visszatérnek. 
Viszonylag részletesen mutatják be a szerzők az osztályfőnöki munka részeként használható szociometriát. Miként kell az adatokat felvenni, értelmezni és kommunikálni. Ez utóbbi különösen nagy körültekintést igényel. A 176. oldalon ezzel kapcsolatban egy számomra érdekes eredményt írtak le a szerzők. Nevezetesen, hogy az 5-8. osztályban a lányok tanulmányi eredménye jobb, és közülük többen töltenek be vezető funkciókat. Kérdéseket vet fel, hogy akkor ez hová tünik el a felnőtt korra hazánkban?

Foglakoznak a szerzők a konfliktusmegoldás lehetséges módjaival is. Itt is megjegyzik, hogy a gyerekkorban tanult mintázatok, tapasztalatok mennyire bennünk élnek. Sőt, feszült helyzetben a gyakorlott tanárok is néha olyan mintát hívnak elő, melyet a nem szeretett tanáraik tettek annak idején. Ezekre megoldás a tudatos odafigyelés lehet.

A személyközi viszonyokkal is külön alfejezet foglakozik, melyben említik a sztereotípiákat, az előfeltételezéseket, az előítéleteket, melyek szerint a valóságot észleljük. Ennek elkerülésére azt javasolják, hogy tudatosítani kell magunkban ennek létezését, és több időt kell hagynunk a benyomások feldolgozására. Ebben a kötetben foglakoznak a szerzők a gyermekek otthoni és iskolai megnyilvánulásainak különbözőségével, amit tudatosítani kell a szülőkben is. Érdekes pszichológiai tétel az ember racionalizálási folyamata, mely szintén ebben az alfejezetben kapott helyet. E szerint döntéseinket sokszor utólag igazoljuk, melynek során hajlamosak vagyunk eltorzítani a valóságot. Az emberre a racionalizálás a jellemző, a racionális gondolkodás helyett, holott szeretünk magunkra mint racionális lényekre gondolni.

Végezetül a harmadik kötetben az egészség- és környezetpszichológia, a problémás tanulók és a pszichés zavarok, az evolúciós pszichológia és a média hatásainak elemei témakörök hangsúlyosak a nevelés és oktatás kontextusában.

A tanárok, elsősorban a pedagógusjelöltek számára is szolgálnak megszívlelendő tanácsokkal a szerzők. Például ne legyenek magukkal szemben irreális elvárásaik. Fel kell ismerniük, hogy a mai társadalomban jóval több elvárás fogalmazódik meg a pedagógusokkal szemben, mint amennyinek egyáltalán lehetséges megfelelni. Továbbá ki kell alakítaniuk a majdani tanároknak egy egészséges egyensúlyt a munka és a magánélet között. Ténylegesen ki is mondják a szerzők a 212. oldalon, hogy ,az emberekkel végzett munkát nem lehet jól csinálni, csak egyre jobban".

A szerzők foglalkoznak a média, elsősorban a tévémüsorok hatásával a gyermeki fejlődésre, és elemzik a gyermek életkorával való változását. Összehasonlítják a filmes ábrázolást és az olvasást, miszerint az utóbbiban sokat kell az agynak dolgozni, hogy jelentést tudjon adni a leírt szövegnek. Érdekes kutatási téma lehet, hogy egy előzőleg csak olvasott, majd megfilmesített történetet hogyan értékel a közönség. Mennyire hasonlít a rendező elképzelése az olvasókéhoz?

Foglakoznak a szerzők a nemiséggel, a biológiai és a társadalmi nem fogalmával. A fejezetből a természettudományos oktatással foglakozó részekre térek ki. 
Érdekes az a 326. oldalon található megállapítás, hogy az iskola korai éveiben a lányok több érdeklődést mutatnak a természettudományos témák iránt, és jobb osztályzatokat is kapnak. Ez azonban a középiskolában megfordul a fiúk javára. Majd a 327. oldalon leírják, hogy a lányok érdeklődése is csökken a természettudományos témák iránt, és inkább szívesebben olvasnak. Érdekes lenne vizsgálni, hogy mi lehet ennek az oka?

Összegzésképp elmondható, hogy a szerkesztők és a szerzők kiváló munkával lepték meg az olvasókat. Ajánlom a tanárjelöltek számára a vizsgákra való felkészüléshez, de a már gyakorló tanárok számára is. A sok-sok iskolai életből vett példa igazán élvezetessé teszi a kötetek olvasását. Többen valószínűleg magukra is ismernek egy-egy leírt helyzetben, szituációban.

(N. Kollár Katalin - Szabó Éva szerkesztök: Pedagógusok pszichológiai kézikönyve I-III. Budapest, 2017)

Radnóti Katalin Eötvös Loránd Tudományegyetem Természettudományi Kar Fizikai Intézet 